\title{
The influence of technological additives and peroxides on the properties of rubber mixtures based on ethylene propylene caoutchouc
}

\author{
(C) Nikolay F. Ushmarin, Lyudmila Yu. Tsareva, Ksenia A. Konnova, \\ Maria V. Yakimova, and Nikolay I. Koltsov** \\ Department of Physical Chemistry and Macromolecular Compounds. Chuvash State University \\ of I.N. Ulyanov. Moskovsky Ave., 15. Cheboksary, 428015. Chuvash Republic. Russia. \\ Phone: +7 (8352) 45-24-68. E-mail: koltsovni@mail.ru
}

\begin{abstract}
*Supervising author; ${ }^{+}$Corresponding author Keywords: technological additives, peroxides, ethylene propylene rubber, rubber mixtures, physical, mechanical and operational properties, heat resistance.
\end{abstract}

\begin{abstract}
The article investigates the influence of technological additives and peroxides on the properties of two rubber mixtures based on ethylene-propylene caoutchouc of marking SKEPT-40. The main properties were: rheometric (maximum and minimum torques; start, optimum and maximum vulcanization rates; maximum vulcanization rates), physical and mechanical (conditional tensile strength, elongation at break, hardness) and operational (changes in conditional strength at tensile, elongation at break and hardness after aging in air). The resistance of rubbers to the action of high temperatures by methods of differential thermal and thermogravimetric analysis was studied. As technological additives, MA-L22, Struktol WS180, Zincolet BB 222 and Struktol A89 were used. Vulcanizing agents were peroxides: Novoperox BP-40, Percodox BC-FF, Dicumyl Peroxide (DK), Chemanox PX1 and Dicumyl Peroxide DCP 99. The studies were carried out for two rubbers, one of which is intended for the manufacture of molded products, and the second rubber - for sealing profiles. It was shown that the technological additive Zincolet BB 222 increases the vulcanization rate of rubber mixture for molded products. All technological additives used have practically no effect on the conditional tensile strength and hardness vulcanizates of molded products, increasing their elongation at break. The smallest changes in the physical and mechanical properties are characterized by the vulcanizate, which contains the technological additive Zincolet BB 222. Technological additives practically do not affect the process of vulcanization of the rubber mixture and slightly affect the process of destruction of rubber during aging. Of the investigated technological additives Zincolet BB 222 is more conducive to improving the thermal properties of rubber. It has been established that Novoperox BP-40 and Chemanox PX1 peroxides increase the rate of vulcanization of the rubber mixture for sealing profiles. For vulcanizates of this rubber mixture, when Novoperox BP-40 and Chemanox PX1 is replaced with other peroxides, a decrease in the conditional tensile strength, hardness and an increase in the elongation at break are observed. With aging in air, changes in the physicomechanical properties of the vulcanizates of the rubber mixture variants containing Novoperox BP-40 and Chemanox PX1 are insignificant and close to each other.
\end{abstract}

\section{References}

[1] I.V. Garmonov. Synthetic rubber. Leningrad: Chemistry. 1976. 752p. (russian)

[2] A.N. Gaidadin, V.F. Kablov. Features of the mechanical behavior of rubbers based on SKEPT at the temperatures of the beginning of the destruction. Kauchuk $i$ rezina. 2000. No.3. P.15-17. (russian)

[3] B.S. Grishin. Materials of the rubber industry (information-analytical database). Kazan: KSTU. 2010. Part 1. 506p. (russian)

[4] J.S. Dick. Rubber technology: formulation engineering and testing. St.Petersburg: Scientific foundations and technologies. 2010. 620p. (russian)

[5] J.S. Dick. How to improve rubber compounds. 1800 practical recommendations for solving problems. SPb.: COP "Profession". 2016. 352p. (russian)

[6] N.I. Koltsov, N.F. Ushmarin, A.E. Petrov, N.P. Petrov, N.N. Petrov, and S.M. Verhunov. Research of influence of technological additives on properties of rubbers on the basis of BNR new generation. Part 1. Vuhtazine RV/g-s. Butlerov Communications. 2010. Vol.19. No.2. P.79-86. ROI: jbc-02/10-19-2-79

[7] N.I. Koltsov, N.F. Ushmarin, L.G. Rogozhina, S.A. Issakova, A.V. Jarutkina, A.Y. Plehanova, and M.V. Kuzmin. Research of influence of technological additives on properties of rubbers on the basis of BNR

Kazan. The Republic of Tatarstan. Russia.

(c) Butlerov Communications. 2019. Vol.60. No.10. 

new generation. Part 2. Elastid, oxsanoles and factice. Butlerov Communications. 2010. Vol.19. No.3. P.75-82. ROI: jbc-02/10-19-3-75

[8] N.I. Koltsov, N.F. Ushmarin, A.E. Petrov, N.P. Petrov, N.N. Petrov, and S.M. Verhunov. Research of influence of technological additives on properties of rubbers on the basis of BNR new generation. Part 3. Novantox 8 PFDA. Butlerov Communications. 2010. Vol.21. No.9. P.22-28. ROI: jbc-02/10-21-9-22

[9] N.I. Koltsov, N.F. Ushmarin, L.G. Rogozhina, S.A. Issakova, A.V. Jarutkina, A.Y. Plehanova, and M.V. Kuzmin. Research of influence of technological additives on properties of rubbers on the basis of BNR new generation. Part 4. Powder stabilizers on a basis novantox 8 PFDA. Butlerov Communications. 2010. Vol.22. No.10. P.42-50. ROI: jbc-02/10-22-10-10-42

[10] N.I. Koltsov, N.F. Ushmarin, N.P. Petrova, Yu.V. Vasileva, A.V. Yarutkina, N.N. Petrova, A.Y. Plekhanova, and M.V. Kuzmin. Research of influence of technological additives on properties of rubbers on the basis of BNR new generation. Part 5. Fire retardants on the basis of trichloroethylphosphate combinations. Butlerov Communications. 2012. Vol.29. No.2. P.62-68. ROI: jbc-02/12-29-2-62

[11] V.A. Surkova, N.N. Petrova, N.F. Ushmarin, N.I. Koltsov. The modifying effect of the technological additive "Lubstab-01" on the properties of molded rubber. Abstracts dokl. Vseros. youth. conf. "Achievements of young scientists: chemical sciences" (Ufa, May 24-27, 2015). P.297-299. (russian)

[12] M.S. Reznikov, N.F. Ushmarin, E.N. Egorov, S.I. Sandalov. Study of the effect of technological additives on the properties of rubbers based on epichlorohydrin and propylene oxide rubbers. Kauchuk $i$ rezina. 2016. No.1. P.18-21. (russian)

[13] L.M. Dyakonova. The use of technologically active additives in elastomers. Kauchuk i rezina. 2007. No.3. P.14-17. (russian)

[14] S.I. Sandalov, N.F. Ushmarin, N.I. Koltsov. The influence of technological active additives on the properties of highly filled rubbers based on BNK and GBNK. All-Russian Scientific Conference "Theoretical and Experimental Studies of the Synthesis, Modification and Processing of Polymers" (Ufa, October 2-5, 2013). Sat abstracts. P.145-146. (russian)

[15] Yu.V. Vasilieva, N.F. Ushmarin, A.I. Khasanov, N.I. Koltsov. The influence of technological additives RS-1 on the elastic-strength properties of rubbers based on BNK. Bulletin of Kazan Technological University. 2013. Vol.16. No.18. P.154-157. (russian)

[16] E.M. Portnova, I.E. Terentyeva, E.N. Egorov, N.I. Koltsov. Investigation of the influence of technological additives on the properties of rubber based on nitrile butadiene rubber. 69th All-Russian Scientific-Technical conf. students, undergraduates and graduate students with international participation of the Yaroslavl state. tech. un-that. (Yaroslavl, April 20, 2016.). Sat materials. P.344346. (russian)

[17] I.S. Spiridonov, N.F. Ushmarin, E.N. Egorov, S.I. Sandalov, N.I. Kol'tsov. Influence of technological additives on the properties of rubber based on nitrile butadiene caoutchouc. Izvestiya vysshikh uchebnykh zavedeniy. Seriya «Khimiya i khimicheskaya tekhnologiya». 2018. Vol.60. No.10. P.53-57. (russian) 